\title{
Startups Can Attract Employees and Financing Through 'Borrowed' Reputations
}

\author{
Daniel Forbes (University of Minnesota)
}

KEYWORDS: Entrepreneurship, Venture Capital, Startups, human resources.

New firms must attract two kinds of resources: talent and money. A recent study that I conducted with Tom Vanacker of Ghent University explored how a new firm's affiliations with venture capital investors shape its attractiveness to potential employees and financiers.

Past research has shown that new firms can enhance their attractiveness to prospective investors by affiliating with more reputable venture capitalists (VCs). But we also know that reputations can have multiple dimensions. Also, reputation is in the eye of the beholder; different groups interpret reputation in different ways.

For our research we looked at how Belgian firms were affected by the reputations of their initial lead VCs. We found that different groups of resource providers responded differently to different dimensions of the VCs' reputation. Employees were more influenced by the VCs' media prominence, whereas future investors were more influenced by the VCs' prior industry experience.

This video summarizes our findings. To see the full article, email me at forbe010@umn.edu(mailto:forbe010@umn.edu), or you can visit the publishers' site at https://pubsonline.informs.org/doi/10.1287/orsc.2016.10 90.

\section{References}

Vanacker, T. \& Forbes, D. 2016. "Disentangling the multiple effects of affiliate reputation on resource attraction in new firms." Organization Science, 27: 1525-1547.

\section{Learn More}

How New Businesses Can Improve Their Chances of Survival(https://eiexchange.com/content/270-how-newbusinesses-can-improve-their-chances-

of?search=Fake\%20it)
Research Insight: Proven Entrepreneurs May Benefit Less From Partnering With Experienced VCs (https://eiexchange.com/content/292-research-insight-p roven-entrepreneurs-maybenefi?search=proven\%20vcs) 